\title{
Descripción de semillas silvestres de Euphorbia strigosa Hook and Arn del estado de Nayarit, México
}

\author{
Description of seeds of wild Euphorbia strigosa Hook \& Arn \\ from the state of Nayarit, México
}

\author{
Edna F. Valdez-Hernández ${ }^{*}$, Porfirio Juárez-López², Martha E. Pedraza-Santos³ ${ }^{3}$ Bernabé L. Zamora-Becerra ${ }^{4}$, \\ Leonardo Martínez-Cárdenas ${ }^{5}$ y María T. Colinas-León ${ }^{6}$
}

Recibido para publicación: Mayo 25 de 2016 - Aceptado para publicación: abril 18 de 2017

\begin{abstract}
RESUMEN
En México, Euphorbia strigosa se ha identificado como una especie con potencial ornamental, por su coloración y su porte pequeño $(35 \mathrm{~cm}$, se considera una versión enana de Euphorbia pulcherrima). La dificultad en la conservación de E. strigosa se encuentra en la gran variabilidad de sus semillas en función de las condiciones ambientales y genotípicas donde la especie crece. Por lo tanto, el objetivo del presente estudio fue describir las semillas de E. strigosa, de plantas silvestres del Estado de Nayarit, México (20132014). Se midieron variables grupales de peso de 1000 y 100 semillas, así como el número de semillas en $1 \mathrm{~g}$ y en $10 \mathrm{~mL}$. Además, una muestra de 130 semillas de cada año se les evaluó individualmente variables físicas. Las semillas se clasifican en función de tres grados de luminosidad del color café (claro, medio y oscuro) y cuatro rangos de peso $(3,0-8,0 ; 8,1-13,0 ; 13,1-18,0$ y $>18,1 \mathrm{mg})$. Basado en la clasificación de los factores: año de colecta, luminosidad del color café y el peso, se formaron 22 subgrupos. En cada subgrupo se evaluó el porcentaje de germinación. Se presentaron diferencias significativas en todas las características evaluadas, lo que indica la diversidad morfogenética de las semillas colectadas.
\end{abstract}

Palabras clave: Euphorbia strigosa, caracterización, semilla, recursos fitogenéticos, silvestre, germinación.

\begin{abstract}
In Mexico, Euphorbia strigosa has been identified as a species with ornamental potential, as a result of its color and small size $(35 \mathrm{~cm}$, is considered a dwarf version of Euphorbia pulcherrima). The difficulty in the conservation of $E$. strigosa is found in the great variability of its seeds depending on environmental and genotypic conditions where the species grows. Therefore, the objective of the present study was to describe the seeds of E. strigosa wild plants of the State of Nayarit, México (2013-2014). Group variables of 1000 and 100 seeds were measured, as well as the number of seeds in 1 $\mathrm{g}$ and in $10 \mathrm{~mL}$. In addition, a sample of 130 seeds from each year were individually assessed for physical variables. The seeds were classified according to three degrees of luminosity of the brown color (Clear medium and dark) and four weight ranges (3.0-8.0; 8.1-13.0; 13.1-18.0 y $>18.1 \mathrm{mg}$ ). Based on the classification of factors: Year of collection, lightness of coffee color and weight, 22 subgroups were formed. In each subgroup the percentage of germination was evaluated. There were significant differences in all characteristics evaluated, which indicates the morphogenetic diversity of the seeds collected.
\end{abstract}

Key words: Euphorbia strigosa, characterization, seed, plant genetic resources, wild, germination.

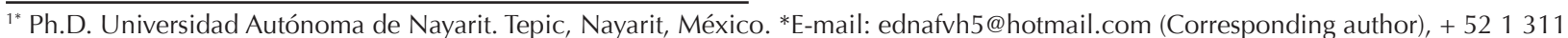
1384192.

${ }^{2}$ Ph.D. Profesor-Investigador, Facultad de Ciencias Agropecuarias. Universidad Autónoma del Estado de Morelos. Cuernavaca, Morelos, México.

${ }^{3}$ Ph.D Profesor-Investigador, Universidad Michoacana de San Nicolás de Hidalgo. Uruapan, Michoacán, México.

${ }^{4}$ Estudiante.Departamento de Fitotecnia. Universidad Autónoma Chapingo, Estado de México, México.

${ }^{5}$ Ph.D. Profesor-Investigador. Secretaria de Investigación y posgrado. Universidad Autónoma de Nayarit. Tepic, Nayarit, México.

${ }^{6}$ Ph.D. Profesor-investigador. Departamento de Fitotecnia. Universidad Autónoma Chapingo, Estado de México, México.
} 


\section{INTRODUCTION}

The family Euphorbiaceae has 300 genera and approximately 7,500 species, most of them herbaceous, although in the tropics they are also present as trees and shrubs. They are monoecious or dioecious, typically with latex; some are succulents that resemble cacti (Steibel 1995). Fruits are capsules that normally open explosively when they mature (Narbona et al. 2005). There are potentially three seeds per capsule with a wide variety of sizes, forms and characteristics of the seed and capsules surface, among species. Among Mexican native Euphorbiaceas, the most remarkable species are Euphorbia pulcherrima, known as "poinsettia" and Euphorbia antispyphilica Zucc, "candelilla" whose importance lies in the vegetable wax for making cosmetics and electronics industry insulation. In agricultural fields the stems of Croton sect. Eluteria are used as stakes (Steinmann 2002), while Jathropha curcas is being studied worldwide as a source of biodiesel (Huse et al. 2011). Other important non Mexican species are Euphorbia tirucalli L, which went from being a medicinal and ornamental plant to a biodiesel source (Kajikawa et al. 2005; Khaleghian et. al. 2011), and Ricinus communis L, oleaginous plant now also being studied as a biodiesel source (Mazzani y Rodríguez 2009). In Mexico, few researchers study the Euphorbiaceae family in depth, although they are found from coast to coast from border to border and from sea level to 3500 meters above sea level (Cházaro y Mostul 1997).

The wild species with ornamental potential, Euphorbia strigosa known as "flor de pascuilla" is considered a dwarf version of E. pulcherrima (Mostul y Cházaro 1996), because it has red or crimson bracts, in addition to having a size smaller than $35 \mathrm{~cm}$ and presents tuberous roots; their seeds are ellipsoid to ovoid, 3.6$3.7 \mathrm{~mm}$ and a thickness of $2.5 \mathrm{~mm}$ (Mayfield 1997). According to information obtained from herbal materials of Mexico and the United States, this species is distributed in the States of Colima, Sinaloa, Sonora, Jalisco and especially in Nayarit. It has been reported that sexual and vegetative propagation is possible (Mostul y Cházaro 1996). However, agronomic characteristics of the wild material and the degree of morphological diversity in populations of E. strigosa, have not been specifically studied. Because of its wild origin and the explosive nature of the fruit it cannot be possible to select fruits with an advanced maturation level. The maturity of the seed and in a population, where plants are subject to different environmental conditions (temperature, water and nutrients), is expected to vary in weight (Milberg et al. 1996), which has implications for the dispersion, viability, germination, emergence, survival and competitive ability of seedlings (Harper et al. 1970; Aguilar-Carpio et al. 2015), which can eventually generate problems in obtaining plants for their cultivation, since the age of the seed may also present a highly variable germination response (Navarro et al. 2014).

Given the invasive nature of some species of the genus Euphorbia, the detection and identification of the seeds is important for agriculture: either for quarantine, prevent an ecological imbalance, the qualification of agronomic products, archaeological and archaeobotanical or productive studies (Pahlevani y Akhani 2011; Araiza-Lizarde et al. 2016). For seed cultivation some basic parameters are considered (weight, moisture content, density and size), since they are closely related to the viability and vigor of the seedling (Poulsen 2000; Doria 2010). Therefore, the objective of the present study was to morphologically describe the seeds of $E$. strigosa from wild plants of the State of Nayarit, Mexico, and their germination evaluated, to obtain basic information to know whether the seed of the species behaves as orthodox, recalcitrant or intermediate, which could have repercussions on their management. 


\section{MATERIALS AND METHODS}

The seeds of E. strigosa were collected during 2013 and 2014 in 14 localities of the State of Nayarit, México (Figure 1). The seeds were weighed in separate groups of 100 and 1000 seeds on an analytical balance $\left(\right.$ Ohaus $^{\circledR}$, model PA232, $\pm 0.001 \mathrm{~g})$; the number of seeds was quantified in $1 \mathrm{~g}$ and $10 \mathrm{~mL}$.

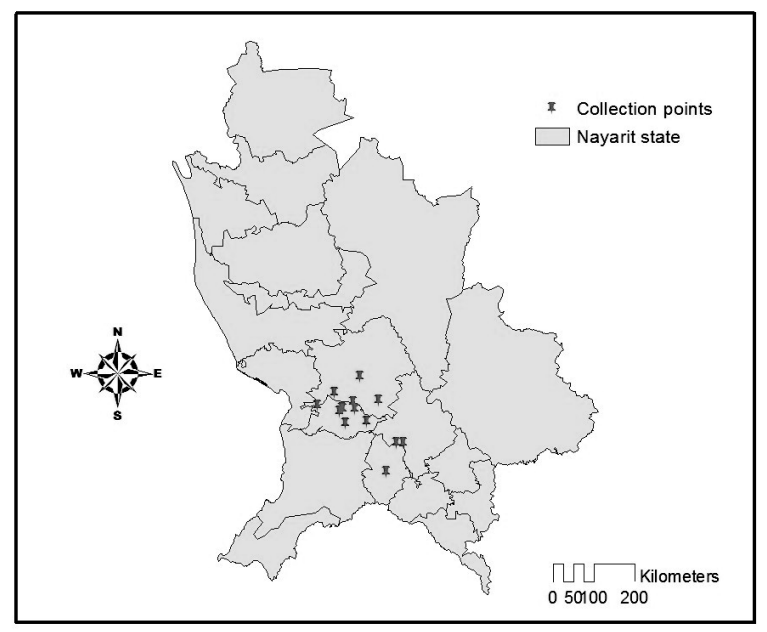

Figure. 1 Municipalities in the State of Nayarit where seeds of Euphorbia strigosa were collected from wild plants during 2013 and 2014.

A 130 seed sample from each year were individually measured for length (L), width (W) and thickness ( $\mathrm{T})$ with a digital micrometer (Neiko $\left.{ }^{\circledR} \pm 0.01 \mathrm{~mm}\right)$. Geometric mean diameter $(\mathrm{mm})(\mathrm{Dg})$ was calculated with the formula $\operatorname{Dg}=[($ L.W.T $)] \wedge(1 / 3)$ and the arithmetic mean diameter(Da) (mm) with the formula $\mathrm{Da}=[(\mathrm{L}+\mathrm{W}+\mathrm{T})] / 3$ (Mohsenin 1978). The surface area $(\mathrm{S})(\mathrm{mm} 2)$ was determined with the equation $\mathrm{S}=\left(\pi . \mathrm{W} \cdot \mathrm{L}^{\wedge} 2\right) /(2 . \mathrm{L}-\mathrm{W})$ (Jain and Bal 1997) and sphericity ( $\phi)$ dimensionless swith $\phi=\mathrm{Dg} / \mathrm{L}$ (Altuntas and Demirtola 2007). The qualitative variable color was determined using the color charts of the Royal Horticultural Society (RHSCC) by placing each seed under a stereo microscope where the main color (present in over $50 \%$ of the seed coat) and secondary (present in less than $50 \%$ of the seed coat) was determined.
Seeds from each year were divided into three grades of brown color brightness [(L) light, (M) medium and (D) dark] (Figure 2) and four weight ranges: T1) $3.0-8.0 \mathrm{mg}$, T2) $8.1-13.0 \mathrm{mg}$, T3) 13.1 - $18.0 \mathrm{~g}$ and T4) > - $18.1 \mathrm{mg}$; combination of these classifications (weight-color, collection-year) resulted in 22 subgroups; since no T4C13 (size four-light-2013) with T4O14 (size four-dark-2014) combinations occurred. From each subgroup a 30 seeds sample was taken except for the groups T3C13, T4M13 and T1013 in which were used 20, 8 and 16 seeds respectively. The seeds were placed in germination trays with a mixture of perlite and peat $(2: 1)$, at an average temperature of $33^{\circ} \mathrm{C}$, with a photoperiod of 16:8 (light-dark), for 20 days. A seeds were considered germinated and emerged when cotyledons were observed on the substrate surface outside the seminal envelope as a result of elongation and hypocotyl erection (Laskowsky y Bautista, 2002).

The experiment treatments were distributed using a complete randomized design.
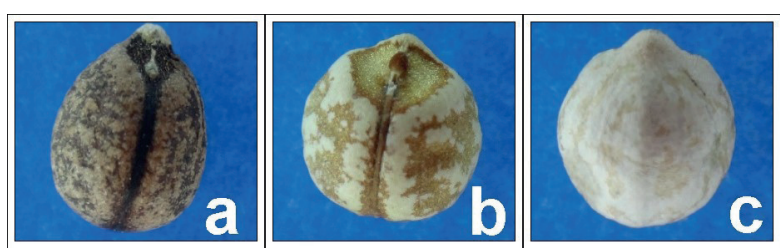

Figure 2. Classification of the seed coat of the seeds of Euphorbia strigosa based on the brightness of color brown; dark (a), medium (b) and light (c).

To evaluate weight of 100 seeds eight replicates were measured, weight of 1000 seeds three replicates, number of seeds in $1 \mathrm{~g}$ and 10 $\mathrm{mL}$ four replicates respectively. For weight, length, width, thickness, arithmetic diameter, geometric diameter, surface area, sphericity and color, 130 experimental units were used, (one experimental unit consisted of a seed). For all quantitative variables an analysis of variance (ANOVA) and Tukey $(p<0.05)$ was used with Statistical Analysis System (SAS) version 9.0. 
The data of germination percentage were transformed with the arcsin formula $\sqrt{x_{2}}$; which subsequently was applied an ANOVA in which the treatments were considered independently with the GLM procedure and Tukey $(p<0.05)$. A second ANOVA was applied to statistically detect significant differences on germination due to seed size, color (brightness) or collection year.

\section{RESULTS AND DISCUSSION}

Significant differences were found $(p<0.05)$ in three groups of the seed characteristics: weight of 1000 seeds ranged from 8.97 to $12.95 \mathrm{~g}$, the lowest weight (9.3 g) was recorded in seeds from 2013. Weight of 100 seeds varied from 0.89 to $1.23 \mathrm{~g}$; seeds from 2013 recorded $1.0 \mathrm{~g}$ average while those collected in 2014 scored $1.2 \mathrm{~g}$. The number of seeds in $10 \mathrm{~mL}$ ranged from 319 to 422 seeds, with seeds from 2013 averaged 415 and those of 2014, 327 seeds. No significant differences were found for $1 \mathrm{~g}$ number of seeds variable ranging between 87 and 112 seeds with an average of 103 seeds collected in 2013 and 95 seeds collected in 2014 (Table 1).

Table 1. Characteristics of Euphorbia strigosa seeds collected in 2013 and 2014 in 14 locations in Nayarit, México.

\begin{tabular}{lrrrr}
\hline \multicolumn{1}{c}{ Variation factor } & Min & Min & $\begin{array}{c}\mathbf{2 0 1 3} \\
\text { mean }\end{array}$ & $\begin{array}{c}\mathbf{2 0 1 3} \\
\text { mean }\end{array}$ \\
\hline Weight of 1000 seeds $(\mathrm{g})$ & 267 & 12.95 & $9.3 \mathrm{~b}$ & $12.2 \mathrm{a}$ \\
Weight of 100 seeds $(\mathrm{g})$ & 8.97 & 1.23 & $1.0 \mathrm{~b}$ & $1.2 \mathrm{a}$ \\
Number of seeds in 10 mL & 0.89 & 422.00 & $415.0 \mathrm{a}$ & $327.0 \mathrm{~b}$ \\
Number of seeds in 1 g & 319.00 & 112.00 & $103.0 \mathrm{a}$ & $95.0 \mathrm{a}$ \\
Weight (mg) & 87.00 & 25.10 & $10.9 \mathrm{~b}$ & $13.0 \mathrm{a}$ \\
Length (mm) & 3.30 & 4.80 & $3.8 \mathrm{~b}$ & $4.0 \mathrm{a}$ \\
Width (mm) & 3.18 & 3.84 & $2.8 \mathrm{~b}$ & $3.1 \mathrm{a}$ \\
Thickness (mm) & 2.42 & 3.86 & $2.7 \mathrm{~b}$ & $3.0 \mathrm{a}$ \\
Geometric diameter (mm) & 2.27 & 3.87 & $3.1 \mathrm{~b}$ & $3.3 \mathrm{a}$ \\
Arithmetic diameter (mm) & 2.74 & 3.84 & $3.1 \mathrm{~b}$ & $3.4 \mathrm{a}$ \\
Surface area (mm²) & 2.68 & 45.15 & $26.3 \mathrm{~b}$ & $31.2 \mathrm{a}$ \\
Sphericity (dimensionless) & 19.74 & 0.97 & $0.8 \mathrm{a}$ & $0.73 \mathrm{a}$ \\
\hline
\end{tabular}

Significant differences were found for all quantitative variables except for sphericity (Table 1). Seed weight ranged from 3.3 to 25.1 mg with about $60 \%$ of the seeds between 9 and $13 \mathrm{mg}$, these weights were found in the seeds of both years, a correlation (0.05) was found between weight and variables: Length (0.45), width (0.62), depth (0.64), arithmetic diameter (0.62), geometric diameter (0.63), surface area (0.62) and sphericity (0.28). The length of the seed varied between $3.19 \mathrm{~mm}$ and $4.80 \mathrm{~mm}$, no correlation was found between years, although a correlation between the width and the thickness was detected (0.6); the width ranged from 2.42 to $3.84 \mathrm{~mm}$, the thickness from 2.27 to $3.87 \mathrm{~mm}$, the geometric diameter from 2.74 to $3.87 \mathrm{~mm}$, the arithmetic diameter from 2.68 to $3.84 \mathrm{~mm}$ and the surface area from 19.74 to $45.15 \mathrm{~mm} 2$. In terms of sphericity, which ranged from 0.73 to 0.97 , no differences were found, confirming the ellipsoid-ovoid shape of the seeds. For the variables weight, width, depth, arithmetic diameter, geometric diameter and surface area, significant differences were found between the two years, with seeds from 2013 scoring lower values than those from 2014.

Of the 47 colors identified, including 12 color ranging from white to black (155-NN155ABCD to 202-203 ABCD) (Table 3), the most frequent were in the orange-gray range (164-177 ABCD) with 15 tones, followed by the white (164-177 $A B C D)$ with seven tones. White tones were more frequently present in the main color in the seeds from both years; however, brown tones (200 ABCD) were identified in 32\% seeds from 2013, and 39\% of seeds from 2014.

In both years the most frequent main color was identified as NN155A and was presented in $34 \%$ of the seeds collected in 2013 and $33 \%$ in 2014. The least frequent main color (less than $1 \%)$ was identified as $155 \mathrm{~A}(0.70 \%)$ in seeds from 2013 and for 2014 those identified as 155B, 155D, 156C, 157B, 164A, 164B, N167A, 177A, N187C, N200B, 201A and 202B (0.30\% each). The most frequent secondary color was N200A (33\%) in 2013 and NN155A (32\%) in 2014. The lowest incidence (less than 1\%) in 2013 was 156A, 158D, 165C and N200B (0.35\%) and in 2014 with NN155B, 158C, 158D, 159B, 164B, 164C, 165C, 166A, 166B, 166C, 177A, 177C, 177D, 198A, 200B, 202B and 203C (0.31\% 
each). In seeds from 2013, 43 combination colors were present (NN155A-N200A whitecoffee presented the highest frequency, 15\%) while in seeds from 2014102 combinations were present (165A-NN155A Greyed-orange to white had the highest frequency, 15\%).

Of these colors were presented 43 combinations in the year 2013, of which NN155A-N200A (white-coffee) presented the highest frequency (15\%) and in 2014102 combinations were presented, of which 165A-NN155A (Greyed-orange to white) had the highest frequency (15\%).

Significant differences in seed germination were found among the 22 subgroups, subgroups of seeds from 2014 except T1O14 and T2C14 had $>50 \%$ germination, $7 \%$ more than the highest percentage of germination registered seeds from 2013. The factorial analysis of germination data (Table 2) indicated that there are significant diffe- rences in the germination of both years, in 2014 the superior presented an average of 47.3 and in 2013 presented an average of 25.8. Regarding the size of the seeds according to the mean test the highest germination was recorded in T3 (13.1 mg-18.0 mg) and T4 (> de $18.0 \mathrm{mg}$ ) with an average of 54 y 51.9 respectively, while the lowest was presented in T1 (3.0 -8.0 mg) with an average of 6.8. In seed color difference was observed only when using statistical error type III.

As for interaction with significant differences (size-year), the means test indicates that the interactions statistically are those of T3 and T4 of the year 2014, with an average germination of 74.2 and 68.2, while the lower ones are the T1 of both years, with an average germination of less than $10 \%$ (Table 3 ).

It was demonstrated that there is great diversity in E. strigosa the seeds collected in the State

Table 2. Color ranges and frequency (\%) present in seeds of Euphorbia strigosa collected in 2013 and 2014 in 14 localities of Nayarit, México.

\begin{tabular}{|c|c|c|c|c|c|c|}
\hline \multirow[b]{2}{*}{ Color ranges } & \multirow{2}{*}{$\begin{array}{l}\text { Code } \\
\text { RHSCC }\end{array}$} & \multirow{2}{*}{$\begin{array}{l}\text { Colors } \\
\text { identified }\end{array}$} & \multicolumn{2}{|c|}{2013} & \multicolumn{2}{|c|}{2014} \\
\hline & & & Primary (\%) & Secundary (\%) & Primary (\%) & Secundary (\%) \\
\hline White & 155-NN155ABCD & 7 & 36 & 12 & 42 & 39 \\
\hline Greyed-white & $156 \mathrm{ABCD}$ & 4 & 0 & 0 & 8 & 15 \\
\hline Green-white & $157 \mathrm{ABCD}$ & 1 & 0 & 0 & 0 & 0 \\
\hline Yellow-white & $158 \mathrm{ABCD}$ & 4 & 19 & 26 & 8 & 4 \\
\hline Orange-white & 159 ABCD & 2 & 0 & 0 & 0 & 0 \\
\hline Greyed-orange & 164-177 ABCD & 15 & 20 & 22 & 25 & 17 \\
\hline Grayed-purple & N187 ABCD & 1 & 0 & 0 & 0 & 0 \\
\hline Grayed-green & 197-198 ABCD & 2 & 0 & 0 & 0 & 1 \\
\hline Gray-brown & 199 ABCD & 1 & 0 & 0 & 0 & 0 \\
\hline Brown & $200 \mathrm{ABCD}$ & 4 & 22 & 32 & 10 & 15 \\
\hline Gray & $201 \mathrm{ABCD}$ & 1 & 0 & 0 & 0 & 1 \\
\hline Black & 202-203 ABCD & 5 & 4 & 8 & 6 & 6 \\
\hline \multicolumn{2}{|c|}{ Total number of colors } & 47 & 17 & 15 & 32 & 45 \\
\hline \multicolumn{2}{|c|}{ Total number of combinations } & & \multicolumn{2}{|c|}{43} & \multicolumn{2}{|c|}{102} \\
\hline
\end{tabular}

Table 3. Results to detect the size infuence, color and year of collection on germination of seeds of Euphorbia strigosa collected in Nayarit, during 2013 and 2014.

\begin{tabular}{|c|c|c|c|c|c|c|c|}
\hline \multicolumn{8}{|c|}{ Variation factor: media } \\
\hline $\begin{array}{l}\text { Weight } \\
\text { Color+ } \\
\text { Year }\end{array}$ & $\begin{array}{l}\text { T1: } \\
\text { Light: } \\
\text { 2013: }\end{array}$ & $\begin{array}{r}6.8 \mathrm{c} \\
30.4 \mathrm{~b} \\
25.8 \mathrm{~b}\end{array}$ & $\begin{array}{l}\text { T2: } \\
\text { Medium: }\end{array}$ & $\begin{array}{l}50.20 \mathrm{~b} \\
40.38 \mathrm{a}\end{array}$ & $\begin{array}{l}\text { T3: } \\
\text { Dark: } \\
2014\end{array}$ & $\begin{array}{l}54.3 \mathrm{a} \\
39.9 \mathrm{ab} \\
47.3 \mathrm{a}\end{array}$ & T4: $51.9 \mathrm{ab}$ \\
\hline \multicolumn{8}{|c|}{$\begin{array}{l}\text { + error type III (Different superscript within a row are significantly different according t } \\
\text { Tukey's test } \mathbf{p}<0.05 \text { ) }\end{array}$} \\
\hline \multicolumn{8}{|c|}{ Interaction Weight-year } \\
\hline & \multicolumn{2}{|c|}{ TT1 } & \multicolumn{2}{|c|}{$\mathrm{T} 2$} & \multicolumn{2}{|c|}{ T3 } & T4 \\
\hline 2013 & \multicolumn{2}{|c|}{$6.6 \mathrm{~d}$} & \multicolumn{2}{|c|}{$33.7 \mathrm{c}$} & \multicolumn{2}{|c|}{$31.9 \mathrm{C}$} & $32.5 \mathrm{c}$ \\
\hline 2014 & \multicolumn{2}{|c|}{$7.0 \mathrm{~d}$} & \multicolumn{2}{|c|}{$46.6 \mathrm{bc}$} & \multicolumn{2}{|c|}{$74.2 \mathrm{a}$} & $68.2 \mathrm{ab}$ \\
\hline
\end{tabular}


of Nayarit, Mexico, during years 2013 and 2014, which may be due to their geographical origin. At each collection site, the plant populations established there are subject to different environmental conditions, such as temperature, moisture and nutrients which can generate difference even in the contents of the chemical composition of the seed (Ayerza 2010; Franco-Mora et al. 2015) (Milberg et al. 1996; Hernández-Verdugo et al. 2012). In addition, it has been documented that wild plants produce variable seed size to ensure prevalence in the habitat as well as dispersion (Baiges et al. 1991). In addition to the explosive feature of the fruits of the Euphorbias, some types of ants present preferences for plants of this family (Narbona et al. 2005; Beaumont et al. 2009; Webster 2013) (Leal et al. 2007; Beaumont et al. 2009; Lôbo et al. 2011). The ants subject the seeds to different conditions (under ground, humidity or variable temperatures or can cause physical damages) that sometimes can favor the germination and formation of seed banks (Martins et. al. 2006). All these mechanisms are necessary to ensure the continuity of a plant species within the ecosystem; since ensuring a high dispersion also helps to avoid competition with their parents and to find different levels in seed banks (Beaumont et al. 2009). Another mechanism in the case of E. strigosa is the production of tuberous roots.

Size variability may allow coexistence through a competition-colonization, since large seeds may have a low percentage of germination and high tolerance to stress, whereas small seeds have a higher percentage of germination and a lower tolerance to stress (Muller-Landau 2010). It has been found that the size of Arabidopsis seeds may be genetically delimited by cytochrome P450 KLUH (KLU)/CYP78A5, which acts as a stimulator of organ growth by the expression patterns of specific genes or crosstalk between maternal inheritance and zygotic controls that regulate in coordinated seed size (Luo et. al. 2005) (García et al. 2005) (Anastasiou 2007), by the expression patterns of specific genes
(Luo et. al. 2005) or crosstalk between maternal inheritance and zygotic controls that regulate in coordinated seed size (García et al. 2005). It is suggested that integument growth limits final seed size (Adamski et al. 2009). On the other hand, there is the hypothesis that seed size evolves as part of a spectrum of life history traits, including plant size, plant longevity, juvenile survival rate and time to reproduction (Moles y Westoby 2006). Or that gene complexes seek adaptation to the environment ( $\mathrm{Xu}$ et al. 2016). It is also thought that a reduction in the number of fruits causes an increase in the mass of individual seed (Jofuku et al. 2005).

When finding the correlation between seed weight and variables such as length, width, thickness, geometric diameter, arithmetic diameter and surface area of E. strigosa, volume and dimension could be used for subsequent studies for the application of some models as predictors of weight (Sánchez et. al. 2002). On the other hand, the values of length and width of the seeds of E. strigosa are greater compared to the 35 Euphorbias studied by Pahlevani $y$ Akhani (2011), where the nearest in long and wide seed to E. strigosa are: E. turkestanica (Length 3.51- $3.42 \mathrm{~mm}$ and width 2.84- 2.61 $\mathrm{mm}$ ) and E. turczaninowii (Length 3.03-2.20 $\mathrm{mm}$ and width 1.83-1.12 mm), it should be noted that in all species in this study (35 species) only in E. sheirolepsis (Std 0.33 long and 1.40 wide) such a wide variability was observed as in the case of E. strigosa (Std 0.31 long and 0.26 wide). When comparing the results of $E$. strigosa with the work of Salmaki et al. (2011) with 85 species of Euphorbia are similarities with the seed dimensions of other 15 species.

In the case of seed color, its variation may be due to the fact that it is an adaptive strategy to produce seeds that can germinate over a wider range of environmental conditions (TenorioGalindo et al. 2008). It is also suggested that the color of the seed varies according to the type of soil in which it grows as a strategy of local 
camouflage, probably driven by the predators of these seeds which gives rise to selection and adaptive divergence in pigmentation (Porter 2013). It has also been found a relation of the color of the seed, with the color of the flower and the resistance to some pathogens such as Xanthomonas campestris pv phaseolis in Phaseolus vulgaris (Duncan et al. 2007). In the case of wheat, the color of the seed affects the yield and quality of the flour (Kuraparthy et al. 2008); in Brassica rapa the yellow seeds have a thinner covering which also contributes to $5-7 \%$ more oil and flour as well as a greater amount of protein (Rahman et al. 2007). In the black lines of Phaseolus vulgaris the protein content, iron and zinc are higher, in lines of other colors are richer in calcium, while the "carioca" is high in magnesium and manganese (Silva etal. 2012). For the case of sesame, color is an important aspect as it is associated with biochemical properties, antioxidants and resistance to diseases (Zhang et al. 2013). In Brassica juncea the yellow color was found in the genotype of the mother, and brown the father, the latter being the dominant (Xu et al. 2010). However, for other species such as Salvia hispanica, no difference was found in seed composition associated with color (Ayerza 2013). In the morphological study developed by Pahlevani and Akhani (2011) with 35 species of Euphorbias, a single color was identified for each species, while for the present study, 12 general shades were found, including 45 colors.

Asfor the results of the percentage of germination, it is possible that the seed of E. strigosa is of the orthodox type like other Euphorbias (GuzmánPozos and Cruz-Cruz 2014), since although the percentage of germination decreased over time, it was still viable in the storage conditions (room temperature) to which was submitted and under the established conditions of germination.

It was found that heavier seeds had a higher percentage of germination, which coincides with results reported by Lobos et al. (2008) in Lupinus and Baraloto et al. (2005) in forest species, since they indicated that the size of the seed influences the growth of the seedling and the density of planting. It is possible that large seeds have a slower growth rate and greater longevity of the plant, whereas small seeds germinate faster, but they die prematurely (Baraloto et al. 2005; Moles et al. 2007). Another explanation might be that smaller wild seeds accumulate lower amounts of biomass in the hypocotyl as observed by Celis-Velazquez et al. (2010), in Phaseolus vulgaris L; hence, the low germination percentage of the small seed (3.0-8.0 mg) in both years for E. strigosa was less than $10 \%$.

The influence of coat color was detected on germination, similar to the one reported in a study with Brassica napus, where it was established that there is a relation between the color of the seed, the content of melanin in the coat and the tolerance to the floods, since the red and black colors presented greater content of melanin and slow absorption of water, whereas the yellow ones to absorb the water more quickly resulting in a lower tolerance to flooding (Zhang et al. 2008). Van Mölken et al. (2005), also found no relationship between seed color and germination in their work with Tragopagon pratensis, but they agree that color can be an adaptation to escape predation.

\section{CONCLUSIONS}

There were significant differences in all characteristics evaluated, which indicates the morphogenetic diversity of the seeds collected. Some attributes are associated with modifications acquired to guarantee the survival of the species in the wild, which may be useful for future studies of genetic improvement and conservation of the species.

\section{ACKNOWLEDGEMENTS}

The first author was financially supported by Consejo Nacional de Ciencia y Tecnología [3539574] and also thanks to the Posgrado 
en Ciencias Biológico Agropecuarias of the Universidad Autónoma de Nayarit., to the Universidad Autónoma Chapingo and the Universidad Michoacana de San Nicolás de Hidalgo for the support during doctoral stays.

\section{REFERENCES}

Adamski, N., Anastasiou, E., Eriksson, S., O’Nell, C. and Lenhard, M. 2009. Local maternal control of seed size by KLUH/ CYP78A5-dependent growth signaling. Proceedings of the National Academy of Sciences 106(46):20115-20120. doi: 10.1073/pnas.0907024106.

Aguilar-Carpio, C., Escalante-Estrada, J. y Aguilar-Mariscal, I. 2015. Análisis de crecimiento y rendimiento de maíz en clima cálido en función del genotipo, biofertilizante y nitrógeno. Terra latinoamericana 33 (1):51-62.

Altuntas, E. and Demirtola, H. 2007. Effect of moisture content on physical properties of some grain legume seeds. New Zealand Journal of Crop and Horticultural Science 35(4): 423-433. doi:10.1080/01140670709510210.

Anastasiou, E., Kenz, S., Gerstung, M., MacLean, D., Timmer, L., Fleck, C. and Lenhard, M. 2007. Control of plant organ size by $\mathrm{KLUH/CYP78A5-dependent}$ intercellular signaling. Developmental Cell 13(6):843-856. doi. http://dx.doi. org/10.1016/j.devcel.2007.10.001.

Araiza-Lizarde, N., Alcaraz-Melendez, L., Angulo-Escalante, M., ReynosoGranados, T., Cruz-Hernández, P., Ortega-Nieblas, M. y Valdez-Zamudio, D. 2016. Caracterización y distribución de germoplasma silvestre de Jatrhopha curcas L. (Euphorbiaceae) en el noroeste de México. Polibotánica 42:137-152. oi.org/10.18387/polibotanica.42.7
Ayerza, R. 2010. Effects of seed color and growing locations on fatty acid content and composition of two chia (Salvia hispanica L.) genotypes. Journal of the American Oil Chemists' Society.87:1161-1165. doi.10.1007/s11746-010-1597-1.

Ayerza, R. 2013. Seed composition of two chia (Salvia hispanica L.) genotypes with differ in seed color. Emirates Journal of Food and Agriculture 25(7):495-500. doi: 10.9755/ejfa.v25i7.13569.

Baiges, J., Espadaler, X. and Blanche, C. 1991. Seed dispersal in W Mediterranean Euphorbia species. Botanical Chronika10: 697-705.

Baraloto, C., Pierre-Michel, F. and Goldberg, D. 2005. Seed mass, seedling size and neotropical tree seedling establishment. Journal of Ecology 93(6):1156-1166. doi. 10.1111/j.1365-2745.2005.01041.x

Beaumont, K., Mackay, D. and Whalen, M. 2009. Combining distances of ballistic and myrmecochorus seed dispersal in Adriana quadripartita (Euphorbiaceae). Acta Oecologica 35(3):429-436. doi:10.1016/j.actao.2009.01.005.

Celis-Velazquez, R., Peña-Valdivia, C., Luna-Cavazos, M. y Aguirre, R. 2010. Caracterización morfológica de las semillas y consumo de reservas durante la emergencia de plántulas de frijol (Phaseolus vulgaris L) silvestre y domesticado. Revista de la Facultad Agronómica (LUZ) 27:61-87.

Cházaro, M. and Mostul, B. 1997. Euphorbia pteronerura Berger: a succulent Mexican spurge. Cactus and Succulent Journal 69(3): 143-146.

Doria, J. 2010. Revisión bibliográfica: generalidades sobre las semillas, su producción, conservación y almacenamiento. Cultivos Tropicales 31(1):74-85 
Duncan, R., Lema, M., Singh, S. and Gilbertson, R. 2007. Linkage between a Xanthomonas campestri spv. phaseoli resistance SCAR marker and flower and seed color in common bean. Phytopathology 97:S30.

Franco-Mora, O., Salomon-Castaño, J., Morales, P., Castañeda-Vildózola, A. y Rubí-Arriaga M. 2015. Ácidos grasos y parámetros de calidad de aceite de semilla de uva silvestre (Vitis spp.). Scentia Agropecuaria 6(4):271-278

García, D., Fitz, G. and Berger, F. 2005. Maternal control of integument cell elongation and zygotic control of endosperm growth are coordinated to determine seed size in Arabidopsis. The plant cell 17(1):52-60. doi.10.1105/tpc.104.027136.

Guzmán-Pozos, A. y Cruz-Cruz E. 2014. Guía técnica para la multiplicación de ocho especies de la selva baja caducifolia. INIFAP, Zacatepec, p 47.

Harper, J., Lovell, P. and Moore, K. 1970. The shape and sizes of seeds. Annual Review of Ecology and Systematics 1:327-356.

Hernández-Verdugo, S., Porras, F., PachecoOlvera, A., López-España, R., VillarrealRomero, M., Parra-Terraza, S. y OsunaEnciso, T. 2012. Caracterización y variación ecogeográfica de poblaciones de chile (Capsicum annuum var. Glabriusculum) silvestre del noroeste de México. Polibotánica 33:175-191.

Huse, S. Narkhede, S. Zope, J. and Singh, N. 2011. Effect of spacing and irrigation in Jatropha curcas Linn. Progressive agriculture 11(2):364-366.

Jain, R. and Bal, S. 1997. Physical properties of pearl millet. Journal of Agricultural Engineering Research 66(2): 85-91.
Jofuku, K., Omidyar, P., Gee, Z. and Okamuro, K. 2005. Control of seed mass and seed yield by the floral homeotic gene APETALA2. Proceedings of the National Academy of Sciences 102(8):3117-3122. doi/10.1073/pnas.0409893102.

Kajikawa, M., Yamato, K., Fukuzawa, H., Sakai, Y., Uchida, H. and Ohyama, K. 2005. Cloning and characterization of a cDNA encoding $\beta$-amyrin synthase from petroleum plant Euphorbia turicalli L. Phytochemistry 66(15):1759-66 doi:10.1016/j.phytochem.2005.05.021.

Khaleghian, A., Nakaya, Y. and Nazari, H. 2011. Biodisel production from Euphorbia turicalli L. Journal of Medicinal Plants Research 5(19):4968-4973. http://www. academicjournals.org/journal/JMPR/ article-full-text-pdf/C73F66426459. [23 may 2016]

Kuraparthy, V., Sood, S. and Gill, B. 2008. Targed genomic mapping of a red seed color gene (R-A1) in wheat. Crop Science 48 supplement 1. S37-S48. doi:10.2135/ cropsci2007.08.0488tpg.

Laskowski, L y Baustista, D. 2002. Efecto de la escarificación y profundidad de siembra sobre la germinación y emergencia de Malpighia emargnata DC. Bioagro 14(2):77-83.

Leal, I., Wirth, R. and Tabarelli, M. 2007. Seed dispersal by ants in the semi-arid Caating of North-east Brazil. Annals of Botany 99(5):885-894. doi:10.1093/aob/mcm017.

Lôbo, D. Tabarelli, M. and Leal, I. 2011. Relocation of Croton sonderianus (Euphorbiaceae) seeds by Pheidolefallax Mayr (Formicidae): a Case of PostDispersal seed protection by ants? Neotropical entomology 40(4):440-444. doi:http://dx.doi.org/10.1590/S1519566X2011000400005. 
Lobos, J., Miranda, H. and Mera, M. 2008. Weightand volumegain by hydrated grains of bitter Albus lupins grown in Chile. In: J.A. Palta and J.B. Berger (Eds). Lupins for Health and Wealth. International Lupin Association. Canterbury, p 105-107.

Luo, M., Dennis, E., Berger, F., Peacock, W. and Chaudhury, A. 2005. MINISEED3 (MINI3), a WRKY family gene, and HAIKU2 (IKU2), a leucine-rich repeat (LRR) KINASE gene, are regulators of seed size in Arabidopsis. Proceedings of the National Academy of Sciences 102(48):17531-17536. doi/10.1073/ pnas.0508418102.

Martins, V., Guimamarâes, P., Da Silva, R. and Semir, J. 2006. Secondary seed dispersal by ants Ricinus communis (Euphorbiaceae) in the Atlantic forest in Southeastern Brazil: Influence on seed germination. Sociobiology 47(1):1-10.

Mayfield, M. 1997. A systematic treatment of Euphorbia subgenus Poinsettia (Euphorbiaceae). Dissertation, University of Texas at Austin. United States.

Mazzani, E. y Rodríguez, E. 2009. Estudio de la variabilidad presente en germoplasma de tártago (Ricinus communis L) en cuanto a racimos, frutos y semillas. UDO Agrícola 9(4):764-769.

Milberg, P., Anderson, L., Elfverson, C. and Regnér, S. 1996. Germination characteristics of seeds differing in mass. Seed Science Research 6:191-198.

Mohsenin, N. 1978. Physical Properties of Plant and Animal Materials. 2nd ed. Gordon and Breach Science Publishers. New York.

Moles, A. and Westoby, M. 2006. Seed size and plant strategy across the whole life cycle. OIKOS 113(1):91-105. doi: 10.1111/j.0030-1299.2006.14194.x.
Moles, A., Ackerly, D., Tweddle, J., Dickie, J., Smith, R., Leishman, M., Mayfield, M., Pitman, A., Wood, J. and Westoby, M. 2007. Global patterns in seed size. Global ecology and biogeography16:109-116. doi: 10.1111/j.1466-822x.2006.00259.x.

Mostul, B. and Cházaro, B. 1996. Two geophytic Euphorbias from Western México. Cactus and Succulent Journal 68(3):153-155.

Muller-Landau, H. 2010. The tolerancefecundity trade-off and maintenance of diversity in seed size. Proceedings of the National Academy of Sciences 107(9):4242-4247. doi/10.1073/ pnas.0911637107.

Narbona, E., Arista, M. and Ortiz, P. 2005. Explosive seed dispersal in two perennial Mediterranean Euphorbia species (Euphorbiaceae). American Journal of Botany 92(3):510-6. doi: 10.3732/ ajb.92.3.510.

Navarro, M., Tzompa, R. y González, E. 2014. Propagación de Echinocactus platyacanthus: efectos del sustrato, viabilidad y escarificación de semillas. Zonas áridas 15(1):31-47.

Pahlevani, A. and Akhani, H. 2011. Seed morphology of Iranian annual species of Euphorbia (Euphorbiaceae). Botanical Journal of the Linnean Society 167(2)212-234. doi: 10.1111/j.10958339.2011.01165.x.

Porter, S. 2013. Adaptive divergence in seed color camouflage in contrasting soil environments. New Phytologist 197(4)1311-1320. doi: 10.1111/ nph.12110.

Poulsen, M. 2000. Análisis de semillas. En. CATIE (ed), Técnicas para la escarificación de semillas forestales. CATIE, Turrialba, $p$ 1-34. 
Rahman, M., McVetty, P. and Li, G. 2007. Development of SRAP, SNP and Multiplexed SCAR molecular markers for the major seed coat color gene in Brassica rapa L. Theoretical and Applied Genetics 115(8):1101-1107. doi 10.1007/s00122007-0636-8.

Salmaki, Y., Zarre, S., Esser, H. and Heub, G. 2011. Seed and gland morphology in Euphorbia (Euphorbiaceae) with focus on the systematic and phylogenetic importance, a case study in Iranian highlands. Flora 206(11):957-973. doi:10.1016/j.flora.2011.07.005.

Sánchez, A., Azcárate, F., Arqueros, L. y Peco, B. 2002. Volumen y dimensiones como predictores del peso de semilla de especies herbáceas del centro de la península Ibérica. Anales Jardín Botánico de Madrid 59 (2):249-262.

Silva, C., Barbosa, A., Patto, R. and Silva, M. 2012. Chemical composition as related to seed color of common bean. Cropbreeding and applied biotechnology 12(2):132-137. doi.org/10.1590/S198470332012000200006 .

Steibel,E.1995.LasEuforbiaceas(Euphorbiaceae Juss.) nativas, naturalizadas y adventicias de la provincia de La Pampa, República Argentina. Revista de la Facultad de Agronomía. Universidad Nacional de La Pampa 8(2): 69-99.

Steinmann, W. 2002. Diversidad y endemismo de la familia Euphorbiaceae. Acta Botánica Mexicana 61: 61-93.

Tenorio-Galindo, G., Rodríguez-Trejo, D. y López-Ríos, G. 2008. Efecto del tamaño y color de la semilla en la germinación de Cecropia obtusifolia Bertol (Cecropiaceae). Agrociencia 42(5):585-593.
Van Mölken, T., Jorritsma-Wienk, D., Van Hoek, P. and De Kronn, H. 2005. Only seed size matters for germination indifferent populations of the dimorphic Tragopogon pratensis subsp. pratensis (Asteraceae). American Journal of Botany 92(3):432-7. doi: 10.3732/ajb.92.3.432.

Webster, G. 2013. Euphorbiaceae. In: Kubitzki $\mathrm{K}$ (ed). The families and genera of vascular plants (Volumen XI). Flowering plants-eudicots Marpiighiales, Dordrecht, p 51-216.

Xu, A., Huang, Z., Ma, C., Xiao, E., Tian, G., Zhan, X., Tu, J., Fu, T. and Zhang, G. 2010. Inheritance of seed color and molecular markers linked to the seed color gene in Brassica juncea. Molecular breeding 25(1):57-65. doi 10.1007/s11032-0099308-5.

Xu, W., Chen, Z., Ahmed, N., Han, B., Cui, $Q$ and Liu, A. 2016. Genome-Wide identification, evolutionary analysis, and stress responses of the GRAS gene family in Castor beans. International Journal of Molecular Sciences 17(7):1004. doi:10.3390/ijms17071004

Zhang, H., Miao, H., Wei, L., Li, Ch., Zhao, R. and Wang, C. 2013. Genetic analysis and QTL mapping of seed coat color in sesame (Sesamum indicum L). Public Library of Science ONE 8(5):e63898. doi:10.1371/journal.pone.0063898.

Zhang, X., Chen, J. and Wang, H. 2008. Imbibition behavior and flooding tolerance of rapeseed seed (Brassica napus L) with different seed coat color. Genetic Resources and Crop Evolution 55(8):1175-1184. doi 10.1007/s10722008-9318-x. 